Susilo Winasis dan Gempur Santoso : Analisis Penggunaan Alat Pelindung Diri (APD) Terhadap Tingkat Kecelakaan Kerja (Studi Kasus : PT. PAL Indonesia)

\title{
ANALISIS PENGGUNAAN ALAT PELINDUNG DIRI (APD) TERHADAP TINGKAT KECELAKAAN KERJA (STUDI KASUS : PT. PAL INDONESIA)
}

\author{
Susilo Winasis $^{1)}$ dan Gempur Santoso ${ }^{2)}$ \\ ${ }^{1)}$ dan 2) Program Studi Teknik Industri, Fakultas Teknologi Industri (FTI) \\ Universitas PGRI Adi Buana Surabaya \\ Email: susilowinasis@ yahoo.com
}

\begin{abstract}
Abstrak
PT PAL Indonesia (Persero) merupakan salah satu perusahaan BUMN di Indonesia yang bergerak di bidang produksi kapal. Jenis APD yang disediakan harus dapat memberikan perlindungan yang kuat terhadap bahaya spesifik yang dihadapi oleh tenaga kerja baik pegawai tetap, kontrakan maupun subkontraktor sesuai dengan jobtittle masing-masing.Tujuan Penelitiannya untuk mengetahui penggunaan alat pelindung diri (APD) terhadap tingkat kecelakaan kerja di bengkel fabrikasi lambung divisi kapal niaga PT PAL Indonesia. Pada penelitian ini termasuk dalam jenis penelitian deskriptif dengan menggunakan metode persentase dalam penyajian data. Hasil penelitian menyebutkan bahwa berdasarkan penggunaan APD di bengkel fabrikasi lambung menunjukkan bahwa dari 44 orang yang dijadikan responden, yang menggunakan APD sebanyak 34 orang (77 \%) dan yang tidak menggunakan APD sebanyak 10 orang (23\%). Berdasarkan tingkat kecelakaan kerja di bengkel fabrikasi lambung menunjukkan bahwa dari 44 orang yang dijadikan responden, yang pernah mengalami kecelakaan kerja sebanyak 11 orang (25\%) dan yang tidak pernah mengalami kecelakaan kerja sebanyak 33 orang (75\%). Berdasarkan dari analisis crosstabulation menunjukkan bahwa ada 7 orang (16\%) yang menggunakan APD pernah mengalami kecelakaan kerja dan pekerja yang tidak menggunakan APD sebanyak 4 orang (9\%) yang pernah mengalami kecelakaan kerja.
\end{abstract}

Kata Kunci : APD, Kecelakaan Kerja, Fabrikasi, K3.

\begin{abstract}
PT PAL Indonesia (Persero) is one of the largest STATE-OWNED ENTERPRISES in Indonesia are engaged in the production of the ship. Types of Personal Protection equipment (PPE) provided should be able to provide reasonable protection against specific hazards faced by laborgood employees remain, rented or subcontractor in accordance with job tittle respectively.To know the use of protective self $(P P E)$ against the level of work accident in the ship's hull fabrication workshops Division Commerce PT PAL Indonesia. In this research included in the types of descriptive researchusing the method of percentage in the presentation of data. Results of the study mentioned that based on the use of PPE fabrication in the workshop showed that the hull of the44 people who were respondents, who use PPE as many as 34 people (77\%) and who do not use PPE as many as 10 people (23\%). Based on the level of work accidents in the workshop the fabrication of the stomach showed that of the 44 people who were respondents, who have experienced accidents as many as 11 people (25\%) and have never had an accident working as many as 33 people (75\%). On the basis of the analysis of the crosstabulation indicates that there are 7 persons (16\%) who use the PPE a work accident and have experienced workers who do not use PPE as much 4 people (9\%) who have experienced work accident.
\end{abstract}

Keywords: PPE, Work Accident, Fabrication, Safety and occupational health. 
Susilo Winasis dan Gempur Santoso : Analisis Penggunaan Alat Pelindung Diri (APD) Terhadap Tingkat Kecelakaan Kerja (Studi Kasus : PT. PAL Indonesia)

\section{PENDAHULUAN}

PT PAL Indonesia (Persero) merupakan salah satu perusahaan BUMN di Indonesia yang bergerak dalam bidang produksi kapal niaga, kapal perang termasuk jasa perbaikan atau pemeliharaannya serta produksi rekayasa umum seperti boiler, steam turbine, wellhead platform dan lain - lain. Dalam proses awal produksi pembuatan kapal niaga maupun bantuan proyek lainnya akan dilaksanakan di bengkel Fabrikasi Lambung Divisi Kapal Niaga (Kania) yang telah memiliki tenaga kerja yang cukup memadai untuk menjalankan suatu proses produksi. Potensi dan faktor bahaya yang tinggi akan selalu menyertai pada setiap pekerjaan, maka alat pelindung diri

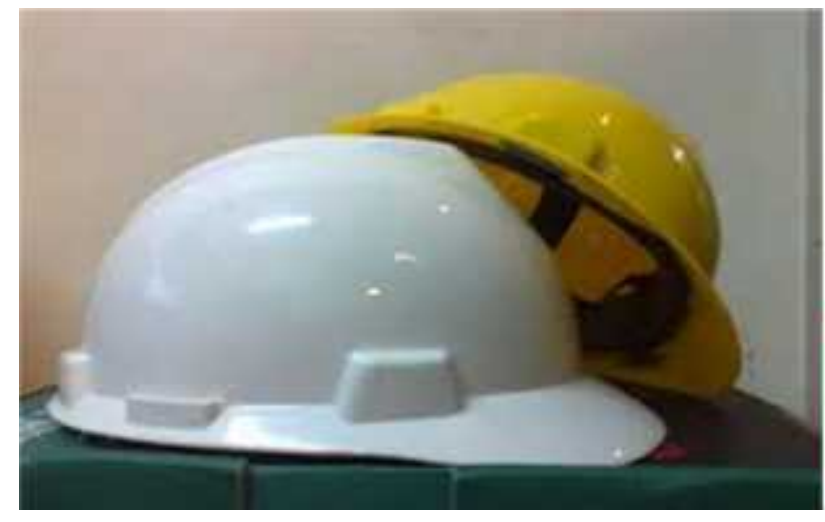

Gambar 1. Helm Safety

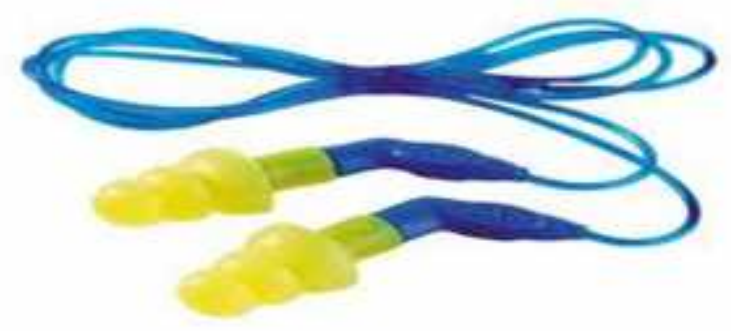

Gambar 3.Earplug

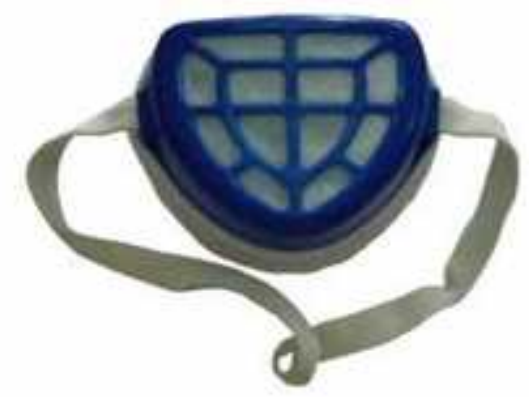

Gambar 5. Masker / Respirator
(APD) sangat diperlukan sebagai bentuk perlindungan terhadap tenaga kerja. Alat Pelindung Diri adalah seperangkat alat keselamatan yang digunakan oleh pekerja untuk melindungi seluruh atau seabagian tubuhnya dari kemungkinan adanya pemaparan potensi bahaya lingkungan kerja terhadap kecelakaan dan penyakit akibat kerja (Tarwaka, 2008). Jenis APD yang disediakan harus dapat memberikan perlindungan yang kuat terhadap bahaya spesifik yang dihadapi oleh tenaga kerja baik pegawai tetap, kontrakan maupun subkontraktor sesuai dengan jobtittle masing-masing. Jenis-jenis APD menurut buku pedoman K3 PT PAL diantaranya seperti pada Gambar 1 sampai 5:

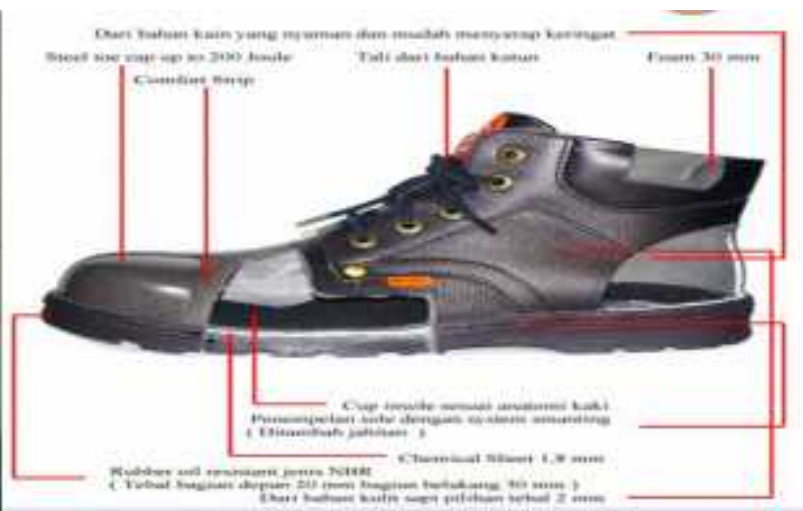

Gambar 2. Sepatu Safety

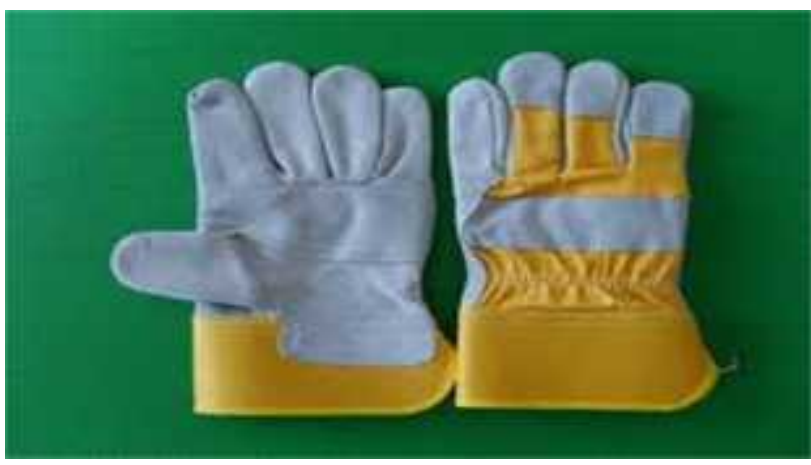

Gambar 4. Sarung Tangan

Kecelakaan Kerja adalah suatu kejadian yang tak diduga dan tidak dikehendaki yang mengacaukan proses suatu aktifitas yang telah diatur (Santoso,2004), , oleh karena itu APD sebaiknya melengkapi program pengendalian bahaya di lingkungan kerja dan berguna untuk meningkatkan safety behaviour para tenaga kerja masing-masing. Menurut Mangkunegara (2002) berpendapat bahwa keselamatan dan kesehatan kerja adalah suatu pemikiran dan upaya untuk menjamin keutuhan dan kesempurnaan baik jasmaniah maupun rohaniah 
Susilo Winasis dan Gempur Santoso : Analisis Penggunaan Alat Pelindung Diri (APD) Terhadap Tingkat Kecelakaan Kerja (Studi Kasus : PT. PAL Indonesia)

tenaga kerja pada khususnya, dan manusia pada umumnya, hasil karya dan budaya untuk menuju masyarakat adil dan makmur.

\section{METODE}

Metode pengumpulan data dari data primer dengan menggunakan teknik pengumpulan data berupa kuesioner.Metode analisis yang digunakan yaitu menggunakan metode persentase.Populasi dalam penelitian ini berjumlah 50 orang sedangkan jumlah sampel ada sebanyak 44 orang.Kegiatan dalam analisa data merupakan mengelompokan data berdasarkan variabel dan jenis responden, mentabulisasi data berdasarkan variabel dari seluruh responden, menyajikan data tiap variabel yang diteliti, melakukan perhitungan untuk menjawab rumusan masalah, dan melakukan perhitungan untuk menguji hipotesis yang telah dilakukan (Sugiyono, 2010). Penulis akan menggunakan metode persentase dalam penyajian data. Menghitung persentase responden dalam bentuk Tabel tunggal melalui distribusi frekuensi dan persentase.dengan menggunakan rumus :

$P=\frac{F}{N} X 100 \%$

Keterangan :

$\mathrm{P}:$ Persentase hasil pengolahan data

F : Frekuensi data

$\mathrm{N}$ : Jumlah sampel yang diolah

\section{HASIL DAN PEMBAHASAN}

Pada awal abad ke-19 tepatnya pada tahun 1822, pemerintah kolonial Belanda dibawah pimpinan gubernur Van de Caplen membentuk suatu komisi penyelidik tempat dan sarana untuk keperluan pendirian "Marine Establishment" (Pendirian dok kapal) dibagian timur Pulau Jawa tetapi pada tahun tersebut tidak dapat terlaksana.

Dengan alasan untuk memperkuat pertahanan dan keamanan, maka pada tahun 1837 dibentuk lagi komisi yang sama dengan tugas yang sama pula. Komisi ini berhasil menentukan tempat dengan pertimbangan : strategi, taktis, dan teknis maka Ujung Surabaya dipilih sebagai lokasi yang memenuhi syarat untuk pendirian dok kapal tersebut. Setelah komisi tadi menetukan Ujung Surabaya sebagai tempat yang cocok maka pada tahun 1846, mulai dilaksanakan pengiriman dok apung dari Belanda ke Indonesia.Pada tahun

1849 pekerjaan tadi baru dapat
diselesaikan.Setelah selesai, pada tahun-tahun berikutnya dibangun bengkel-bengkel khusus yang berhubungan dengan pekerjaan perkapalan.

Setelah berdiri, Marine Establishment berkembang dengan pesat.Terbukti dengan bertambahnya area dan dibangunnya galangan kapal yang cukup besar sehingga mampu membuat kapal baru dengan ukuran 1300 ton. Selain itu juga dibangun pula fasilitas untuk membuat dan perbaikan mesin-mesin kapal dengan namaVoor de Marine Stoomven. Dengan perkembangan yang sangat cepat dan pesat, maka pada tahun 1939 no.82 Marine Establishment dinyatakan sebagai perusahaan Negara Hindia Belanda (Landsbeijj). Perusahaan ini mempunyai tugas utama yaitu melaksanakan semua pekerjaan pemeliharaan dan perbaikan kapal-kapal perang Belanda serta mengurus perlengkapan dan perbendaharaan kapal-kapal tersebut.Selain itu, juga melaksanakan perbaikan kapal-kapal sekutu yang mengalami kerusakan akibat perang.

Pada tahun 1942 saat Belanda menyerah kepada Jepang, namaMarine Establishment diubah menjadi Kaigun SE 21-24 Butai, dengan tugas yang sama. Nama Kaigun tidak berlangsung lama seiring menyerahnya Jepang terhadap Sekutu yang didalamnya terdapat Belanda sehingga namanya kembali kesemula.Pada saat itu keadaannya rusak berat akibat perang, sehingga perlu dilakukan perbaikan kembali. Pada tanggal 27 Desember 1949 ketika pemerintah Kolonial Belanda mengakui dan menyerahkan kedaulatan kepada pemerintah Indonesia,maka namaMarine Establishment diubah menjadi Penataran Angkatan Laut yang disingkat PAL yang seluruh penguasaannya langsung dibawah Kementerian Pertahanan. Pada tahun 1957 setelah keluar Surat Keputusan Menteri Pertahanan tentang penyelenggaraan PAL dibidang administrasi (Organisasi Financial), teknis dan soal-soal yang berhubungan dengan pengamanan PAL sebagai proyek vital dan strategis diserahkan kepada KASAL. Setelah itu perubahan ditubuh PAL terjadi terusmenerus sehingga pada tahun 1980 dengan adanya PP/No.14/1980, maka status PAL diganti menjadi persero. Dengan akte pendirian No.12 tanggal 15 April 1980, maka galangan kapal ini diresmikan dengan nama PT. PAL INDONESIA (Persero) sampai sekarang.Data penelitian yang telah didapatkan dari hasil kuesioner yang telah disebar di bengkel 
Susilo Winasis dan Gempur Santoso : Analisis Penggunaan Alat Pelindung Diri (APD) Terhadap Tingkat Kecelakaan Kerja (Studi Kasus : PT. PAL Indonesia)

fabrikasi lambung tertera padaTabel 1 dan 2 sebagai berikut:

Tabel 1. Data Penggunaan APD

\begin{tabular}{lcccccc}
\hline \multirow{2}{*}{ Jenis APD } & \multicolumn{3}{c}{ Menggunakan } & \multicolumn{3}{c}{$\begin{array}{c}\text { Tidak } \\
\text { Menggunakan }\end{array}$} \\
\cline { 2 - 7 } & T & C & G & T & C & G \\
\hline Sepatu Safety & 13 & 13 & 5 & 5 & 1 & 7 \\
Helm Safety & 18 & 14 & 12 & 0 & 0 & 0 \\
Masker & 9 & 7 & 5 & 9 & 7 & 7 \\
Earplug & 9 & 3 & 4 & 9 & 1 & 8 \\
Gloves & 11 & 6 & 8 & 7 & 8 & 4 \\
KacamataSafety & 3 & 8 & 7 & 15 & 6 & 5 \\
\hline
\end{tabular}

Keterangan :

$\mathrm{T}=$ Transportasi

$\mathrm{C}=$ Cutting

$\mathrm{G}=$ Gerinda

Berdasarkan Tabel 1 telah didapatkan data penggunaan APD yakni bahwa Helm merupakan APD yang wajib dipakai oleh setiap pekerja dalam saat proses produksi berlangsung. Sedangkan para pekerja yang menggunakan earplug masih kurang atau minimum.

Tabel 2. Data Kecelakaan Kerja

\begin{tabular}{lcccccc}
\hline \multirow{2}{*}{\multicolumn{1}{c}{ Jenis Kecelakaan }} & \multicolumn{3}{c}{ Pernah Mengalami } & \multicolumn{3}{c}{ Tidak Mengalami } \\
\cline { 2 - 8 } & T & C & G & T & C & G \\
\hline Kaki TertimpaBahan Material & 5 & 3 & 7 & 13 & 11 & 5 \\
Kepala Kejatuhan/ Terbentur & 1 & 1 & 1 & 17 & 13 & 12 \\
Gangguan Pernapasan & 9 & 3 & 5 & 9 & 11 & 7 \\
Telinga merasa sakit & 10 & 2 & 6 & 8 & 12 & 6 \\
Tangan Terjepit/Tergores & 6 & 7 & 4 & 12 & 7 & 8 \\
Mata terkena gram/Serpihan besi & 0 & 0 & 5 & 18 & 14 & 8 \\
\hline
\end{tabular}

Keterangan :

$\mathrm{T}=$ Transportasi

$\mathrm{C}=$ Cutting

$\mathrm{G}=$ Gerinda

Berdasarkan Tabel 2 menunjukkan bahwa dari 44 pekerja yang paling sering terjadi jenis kecelakaan kerja ialah telinga para pekerja merasa sakit atau pendengaran menurun karena disebabkan pekerja tersebut tidak menggunakan earplug pada saat bekerja dan akan dapat mengakibatkan efek yang buruk pada telinga pekerja dalam jangka panjang.

Tabel 3. Sebaran Frekuensi Penggunaan APD

\begin{tabular}{clll}
\hline & Frequency & Percent & Valid Percent \\
\hline Valid Menggunakan APD & 34 & 77 & 77.27 \\
Tidak Menggunakan APD & 10 & 23 & 22.73 \\
Total & 44 & 100.00 & 100.00
\end{tabular}

Berdasarkan dari Tabel 3 tersebut menunjukkan bahwa dari 44 orang pekerja yang bekerja di bengkel fabrikasi lambung yang menggunakan APD sebanyak 34 orang (77 \%) dan yang tidak menggunakan APD sebanyak 10 orang (23\%). 
Susilo Winasis dan Gempur Santoso : Analisis Penggunaan Alat Pelindung Diri (APD) Terhadap Tingkat Kecelakaan Kerja (Studi Kasus : PT. PAL Indonesia)

\section{Tabel 4. Sebaran Frekuensi Kecelakaan Kerja}

\begin{tabular}{lrrr}
\hline & Frequency & Percent & Valid Percent \\
\hline Valid Pernah Mengalami Kecelakaan & 11 & 25 & 25 \\
Tidak Pernah Mengalami Kecelakaan & 33 & 75 & 75 \\
Total & 44 & 100.00 & 100.00 \\
\hline
\end{tabular}

Berdasarkan Tabel 4 menunjukkan bahwa dari 44 orang pekerja yang pernah mengalami kecelakaan kerja pada saat bekerja sebanyak 11 orang $(25 \%)$ dan kategori yang tidak pernah mengalami kecelakaan kerja pada saat produksi sebanyak 33 orang $(75 \%)$.

Tabel 5. Distribusi Silang (Crosstabulation)

\begin{tabular}{|c|c|c|c|c|c|}
\hline & & & Kecelak & an Kerja & \\
\hline & & & $\begin{array}{l}\text { Pernah } \\
\text { Mengalami }\end{array}$ & $\begin{array}{c}\text { Tidak } \\
\text { Pernah } \\
\text { Mengalami }\end{array}$ & Total \\
\hline & Menggunakan & Count & 7 & 27 & 34 \\
\hline PenggunaanAPD & & $\%$ of Total & $16 \%$ & $61 \%$ & $77 \%$ \\
\hline & Tidak & $\begin{array}{l}\text { Count } \\
\% \text { of Total }\end{array}$ & $\begin{array}{r}4 \\
9 \%\end{array}$ & $\begin{array}{r}6 \\
14 \%\end{array}$ & $\begin{array}{r}10 \\
23 \%\end{array}$ \\
\hline Total & Menggunakan & Count & 11 & 33 & 44 \\
\hline & & $\%$ of Total & $25 \%$ & $75 \%$ & $100 \%$ \\
\hline
\end{tabular}

Bahwa pekerja yang tidak menggunakan APD dan juga pernah mengalami kecelakaan kerja sebanyak 4 orang $(9 \%)$; kemudian yang tidak mengalami kecelakaan sebanyak 6 orang (14\%).Selanjutnya pekerja yang dalam kategori menggunakan APD yang pernah mengalami kecelakaan kerja sebanyak 7 orang $(16 \%)$ dan yang tidak pernah mengalami kecelakaan kerja sebanyak 27 orang (77 \%).Berdasarkan dari Tabel distribusi silang tersebut dapat disimpulkan bahwa penggunaan APD terhadap tingkat kecelakaan kerja sangat rendah di bengkel fabrikasi lambung divisi kapal niaga.

Dari analisis penyajian data dan analisis data maka dapat diberikan interpretasi yang merupakan garis besar penelitian sebagai berikut :

1. Berdasarkan penggunaan APD dalam bekerja di bengkel fabrikasi lambung PT PAL Indonesia menunjukkan bahwa dari 44 orang pekerja yang dijadikan responden, yang menggunakan APD sebanyak 34 orang $(77 \%)$ dan yang tidak menggunakan APD sebanyak 10 orang (23 $\%)$. Menurut Absari (2006) mengenai penggunaan APD adalah sebagai salah satu upaya menjaga keselamatan dalam bekerja sehingga pekerja dapat bertanggung jawab apabila terjadi kecelakaan karena tidak menggunakan APD. Pengertian alat pelindung diri (APD) menurut Suma'mur
(1992) adalah suatu alat yang dipakai untuk melindungi diri atau tubuh terhadap bahaya-bahaya kecelakaan kerja. Dari pendapat-pendapat tersebut peneliti menyimpulkan bahwa penggunaan APD sangatlah penting dalam melakukan proses produksi karena APD berguna untuk melindungi diri serta mengurangi potensi bahaya dalam bekerja.

2. Berdasarkan tingkat kecelakaan kerja di bengkel fabrikasi lambung menunjukkan bahwa dari 44 orang pekerja yang dijadikan responden, yang pernah mengalami kecelakaan kerja sebanyak 11 orang $(25 \%)$ dan yang tidak pernah mengalami kecelakaan kerja sebanyak 33 orang (75\%). Menurut Silalahi (1995) mengatakan bahwa kecelakaan kerja adalah setiap perbuatan / kondisi tidak selamat yang dapat mengakibatkan kerugian baik individu maupun kelompok. Dari pendapat tersebut peneliti menyatakan bahwa kecelakaan kerja dapat dialami oleh setiap pekerja meskipun APD yang digunakan sudah lengkap dan benar namun kualitas dari APD tersebut juga dapat mempengaruhi terjadinya kecelakaan kerja.

3. Berdasarkan dari analisis crosstabulation menunjukkan bahwa ada 7 orang (16\%) yang menggunakan APD pernah 
Susilo Winasis dan Gempur Santoso : Analisis Penggunaan Alat Pelindung Diri (APD) Terhadap Tingkat Kecelakaan Kerja (Studi Kasus : PT. PAL Indonesia)

$\begin{array}{lllr}\text { mengalami kecelakaan kerja dan pekerja } & \text { saat bekerja.Hal ini baik dilakukan untuk } \\ \text { yang tidak menggunakan APD sebanyak } 4 & \text { menghindari } & \text { hal-hal } & \text { yang } \\ \text { orang }(9 \%) \text { yang pernah mengalami } & \text { tidak diinginkan terjadi pada saat bekerja. }\end{array}$

kecelakaan kerja. Menurut Widarto (2008)

mengatakan bahwa APD berkemampuan

untuk melindungi seseorang dalam pekerjaan yang fungsinya mengisolasi tubuh dari bahaya ditempat kerja. Dari pendapat tersebut serta hasil dari analisis crosstabulation peneliti menyatakan bahwa pekerja yang menggunakan APD lebih banyak pernah mengalami kecelakaan kerja daripada pekerja yang tidak menggunakan APD di bengkel fabrikasi lambung divisi kapal niaga.

Diketahui bahwa perusahaan menyediakan APD dengan standart kualitas yang baik. Saat ini perusahaan sudah menyediakan APD sesuai dengan potensi bahaya di tempat kerja, namun APD yang disediakan kurang memenuhi standart kualitas sesuai dengan Job Tittle masing-masing pekerja, PT PAL Indonesia telah memiliki peraturan tersendiri mengenai penggunaan APD tetapi belum diterapkan secara maksimal. Agar penggunaan APD lebih meningkat, sebaiknya peraturan yang ada dipertegas dengan diberlakukannya sanksi dan penghargaan terhadap pekerja yang melanggar dan mematuhi peraturan tersebut, serta Pekerja diharapkan dapat saling mengingatkan rekan

\section{KESIMPULAN}

PT PAL Indonesia merupakan perusahaan yang bergerak dalam bidang produksi perkapalan dalam pelaksanaan kegiatan produksinya, keselamatan dan kesehatan kerja merupakan hal yang vital bagi setiap para pekerja maka perlu diukur respon penggunaan APD terhadap tingkat kecelakaan kerja dan dari hasil penelitian tersebut diperoleh hasil sebagai berikut bahwaberdasarkan dari analisis crosstabulation dapat disimpulkan bahwa pekerja yang menggunakan APD lebih banyak tidak mengalami kecelakaan kerja daripada pekerja yang tidak menggunakan APD di bengkel fabrikasi lambung divisi kapal niaga.

\section{UCAPAN TERIMA KASIH}

Ucapan terima kasih dan penghargaan perlu penulis sampaikan kepada berbagai pihak yang telah memberikan bantuan berupa bimbingan, arahan, saran, dukungan dan kemudahan sejak awal sampai akhir penyusunan Tugas Akhir ini. kerjanya apabila tidak menggunakan APD pada

\section{DAFTAR PUSTAKA}

Absari, Rafika. 2006. Gambaran Penggunaan APD Pada Bagian Produksi Kulkas/Frezeer Di PT Sharp Elektronik Indonesia, Laporan Magang FKM UI, Depok

Mangkunegara, 2002.Manajemen Sumber Daya Manusia. Bandung: Penerbit PT Remaja Rosda Karya.

Santoso, Gempur. 2004. Manajemen keselamatan dan kesehatan kerja. Jakarta: Penerbit Prestasi Pustaka.

Silalahi, Bennet. 1995. Manajemen keselamatan dan kesehatan kerja. Jakarta: Penerbit PT Binaaan Pustaka Pressindo.

Sugiyono. 2010. Metode penelitian kuantitatif, kualitatif dan $R \&$ D. Bandung: Penerbit Alfabeta.

Tarwaka. 2008. Keselamatan dan Kesehatan Kerja. Surakarta: Penerbit Harapan Press.

Widarto. 2008. Teknik Permesinanan Jilid 2. Jakarta: Penerbit Departemen Pendidikan Nasional. 